\title{
How Consumer Perceptions of Fusion Drinks Lead to Consumer Purchasing Decisions?
}

\author{
Sabilla Saberina* and Ratih Hadiantini
}

\author{
Department of Management, Universitas Informatika dan Bisnis Indonesia, Bandung, Indonesia \\ *Corresponding author: sabillasaberina@unibi.ac.id
}

\begin{abstract}
The lifestyle of the people is now influenced by modernization in various fields so that it encourages people to make adjustments by following developments that are happening in the current Covid 19 pandemic. Many foreign investors have finally competed to fill the Indonesian market in order to enliven the culinary competition of course. The trend of a popular fusion drink, namely Chat time, is one of the beverage trends that are currently mushrooming in various circles. Current consumer behavior has a special impact from the pandemic that occurs. Ironically, the Consumer Confidence Index (IKK) is decreasing in the current pandemic era, so that individual attitude patterns indirectly change the pattern of decisions that consumers usually make. This makes motivation and perceptions change automatically. This is a special challenge for the Food and Beverage industry in the future to be able to rebuild consumer perceptions in order to increase optimism. This study uses a descriptive method with a quantitative approach where research tries to describe a symptom, event and incident that is happening at the present time where the researcher tries to summarize the events and incidents that are the center of attention to then be described as they are by measuring the indicators of research variables so that they are obtained a description of these variables, to measure the dimensions to be studied.
\end{abstract}

\section{Keywords: Consumer Perceptions, Consumer Purchasing Decisions, Consumer Confidence}

\section{INTRODUCTION}

Food and drink are basic needs for everyone, the need for food and drink for each person varies based on desires and is influenced by various factors from within and outside a person. The food and beverage industry is projected to still be the mainstay of the sector that supports the growth of manufacturing and the Indonesian economy. Based on this, the food and beverage business is currently very diverse. The phenomenon that is currently happening is thetrend fusion drink. Call it bubble tea, milk tea, cheese tea, and contemporary iced coffee milk. Unexpectedly, this product received a positive response from the public. Quoted from Allied Market Research, it is explained that the trend of fusion drinks is experiencing an increasing growth from year to year. "The bubble tea market was valued at $\$ 2,4$ billion in 2019 and is estimated to reach $\$ 4,3$ billion by 2027, registering a CAGR of $7.80 \%$ from 2020 to 2027 . In 2019 , the black tea segment accounted for more than half of the share in the total bubble tea market and is expected to grow at a CAGR of $7.50 \%$ throughout the forecast period" [1]. One of fusion drinks the most popularis bubbble tea. Bubble tea market is worth $\$ 2.4$ billion in 2019 and is estimated to reach $\$ 4,3$ billion in 2027 , recording a CAGR of $7.80 \%$ from 2020 to 2027. In 2019, the black tea segment accounted for more than half of the total market share. bubble tea market and is expected to grow at a CAGR of $7.50 \%$ across the forecast period. This is certainly the best trend in history.

Many foreign investors have finally competed to fill the Indonesian market in order to enliven the culinary competition of course. One of them is the bubble tea company from Taiwan, Chatime, which is well known and has long occupied the market share of bubble tea drinks in Indonesia. Chatime is a franchise beverage outlet that is under the auspices of PT Food Beverage IndonesiaKawan Lama Group, in 2014 Chatime represented one of 
the Asian brands who managed to get the award of the 2014 World Branfing Award.

$\mathrm{T}$ least 1002 branches in 26 countries, and has spread approximately 300 outlets in major cities in Indonesia. Chatime has qualities that are recognized in the international market [2]. Many menu variations and toppings are also one of the attractions of consumers. In addition, Chatime also provides services for the freedom to choose the type of tea, toppings, the amount of sugar, the number of ice cubes, and the cup served by the drink. Where not all beverage manufacturers provide a wide variety of menus and toppings that are served, making Chatime not lose its fans. Not only that, Chatime also tries to pamper its customers by releasing various innovations. The Chatime company has a distinct attraction in maintaining its market share is a major concern in the purchasing decision factor of its consumers. The influence of the social environment is very strong on adolescents, who in this case are friends or family, so that this can also influence the purchasing decisions of adolescents towards drinks that are currently being discussed. The existence of lifestyle changes can also affect the purchase decision of a product. Purchasing decisions can be assumed that all actions that determine all available options to be selected through a series of stages of the process. One dimension of the success of a business is what consumers perceive to be in order to increase confidence in a product so that they have a very large desire to buy the product. This can be identified by assessing consumer perceptions. Evaluation results can be measured by comparing the information contained in the field. For several types of companies, the evaluation results have a perception or opinion of consumers which has a very significant role in making decisions. Psychological aspects that have the character to take into account an object are a perception. Consumer perception is a process used by people to be able to sort, organize, and interpret data input to produce reflections that have meaning [3].

The behavior of people's lives today is influenced by the presence of modernization in various fields, thus urging the community to adapt to the existing growth adaptations. However, this is ironic if it is related to the conditions that hit the world today where the current concern is related to conditions that are increasingly hunting with the presence of COVID 19, where the survey depicts the development of the current Economic Condition Index, affecting the Consumer Confidence Index (IKK) last month move to a pessimistic level. The CCI was recorded at 71.4 alias decreased $1.8 \%$ mom from the previous month which was 72.6. The reflection of how important the food and beverage industry is can be seen from how much effort it makes to contribute to the gross domestic product (GDP) of the non-oil and gas industry in the country. This makes the food and beverage sector one of the largest contributors to GDP. However, this also changed with the current pandemic, it was noted that there was a sharp decline in which thesector, accommodationboth the food and beverage industry, also contributed to reducing the growth percentage of $6.41 \%$ in the first quarter of 2019 to $1.95 \%$ [1]. The Central Statistics Agency noted that there was a significant decrease in household expenditure or consumption, which only grew $2.84 \%$. This can be measured by making comparisons with the same period last year which grew by $5.02 \%$. In fact, household spending contributes more than half of Indonesia's GDP. [4] This may indicate an assumption that consumers give a decreasing (negative) view of the current economic conditions. Thus, the lifestyle of current consumer spending needs can be reflected in the possibility of decreasing the perception of consumer spending which in the end can reduce consumer confidence in deciding product purchases. In this case, the role of business activists is needed here, because they are the ones who provide the various needs that everyone wants. Therefore, business activists must continue to innovate to meet the needs and desires of everyone by restoring consumer confidence through a good packaging and management process that is adjusted to current health protocols and standards.

In fact, if you examine the purchase motivation related to consumer spending in early 2019 , the condition shows the growth of the penchant for consuming fusion drinks continues to grow very well with a wide variety of product variants. Chatime can be said to be excellent for millennials in the last few years. Initially in making a purchase, consumers make definite decisions based on purchase motivation. There are various reasons starting in terms of price, product quality, prestige, place, lifestyle and others. This will certainly build consumer perceptions. Because it can be said that it is the consumer's perception that will move or attract consumers or buy an item. In connection with the existence of consumers and their various behaviors, producers must be really responsive to observe what they want. So basically entrepreneurs have an obligation to meet and satisfy consumers through the products offered. There are two factors that can influence consumers, namely internal and external factors. internal factors that can influence consumer behavior include: 1) motivation and 2) perception [5]. Meanwhile, motivation can be described as the driving force in individuals that drives them to action [6]. In this case the consumer's interest in buying is certainly influenced by the conditions that occur. A fussion drink is a drink that has a rating requirement only as a secondary need. So it cannot be denied that what is happening at this time the motivation for consumer spending indirectly may continue to decline because along with the decrease in the index of consumer confidence in consuming food or drinks due to Covid 19. People have flocked to isolate themselves and take better care of their health, one of which is by only processing 
food which can be done by yourself. This is a side effect of the paralysis of public trust in anyone to avoid being exposed to the virus that is currently spreading. This is a special challenge for the Food and Beverage industry in the future to be able to rebuild consumer perceptions in order to increase optimism, of course. Therefore, the authors will examine how much influence the motivation and perceptions of consumers on purchasing decisions by looking at the various factors that will eventually emerge and can still be maintained in order to increase various types of motivation, consumer perceptions that ultimately produce the purchasing decisions that everyone wants to buy. Chatime brand.

\section{LITERATURE REVIEW}

\subsection{Theorical Framework}

This study contributes to providing a conceptual framework in defining the concept of nature and collaborates with previous reference studies.

Behavior is an act of social relations and actions taken by individual consumers, groups and organizations to assess, obtain and use goods and services through an exchange or purchase process that begins with a decision-making process that determines these actions. consumer behavior is the study of individuals, groups or organizations and the processes they use to select, obtain, use and stop using products, services, experiences or ideas to satisfy needs, and impacts. These processes towards consumers and society.

\subsection{Hypothesis Development}

\subsubsection{Motivation}

Handoko (2011) states that motivation is a situation in a person that encourages an individual's desire to carry out certain desires in order to achieve goals [5]. There are several motivational indicators which consist of rational motivation and emotional motivation. Solomon (2012) mentions "rational purchase motivation as a utilitarian need, namely a desire to obtain functional or practical benefits from the products consumed" [7], while Emotional motivation in purchasing is related to feelings, pleasures that can be captured by the five senses, for example by owning a certain item can increase social status, the role of brands makes buyers show their economic status and is generally subjective and symbolic [8].
H1 = Motivation has a positive effect on purchasing decisions.

\subsubsection{Consumer Perception}

"Perception is process by which an individual selects, organizers, and interprets stimuli into the meaningfull and coherent picture of the world" [6]. It can be stated that, perception is defined as the process by which individuals select, organize, and interpret stimuli into meaningful and plausible images of the world [9]. This process can be described as "How we see the world around us". Two individuals may receive the same stimuli under the same real conditions, but how each person recognizes, chooses, arranges, and interprets them is a very individual process based on each person's own needs, values and expectations. The effect that each of these variables exerts on the process of acquiring perceptions and their relationship to marketing will be studied in detail. There are two indicators that form consumer perceptions, namely Product Quality and Product Value. So that these two indicators are expected to measure the formation of consumer perceptions in measuring the perspective of consumer perceptions. Where the following hypothesis is obtained:

$\mathrm{H} 2=$ Consumer Perceptions Influence Purchasing Decisions

\subsubsection{Purchasing Decisions}

The purchasing decision is the selection of two or more alternative purchasing decisions, meaning that someone can make a decision, there must be several alternative options available. The decision to buy can lead to how the process of making the decision is carried out [6]. the purchase decision is a decision stage where consumers actually purchase a product [10]. Based on the above definition, it can be concluded that the purchase decision is a decision that is influenced by several factors that will make consumers actually consider everything and in the end consumers buy the product they like the most. Indicators and Decision Making Processes are divided into several parts. A consumer in buying a product will see a product from various points of view. This is called the stages of the purchasing decision process. According to Kotler (2012) the consumer purchasing decision process consists of five stages carried out by a consumer before arriving at a purchase decision and then post-purchase [11]. When the decision becomes a stage where consumers can actually decide, several approaches are obtained to measure the decision. The purchase is described below: 
1) Problem Recognition (Introduction Problems) at this stage consumers know there is a problem or a need that must be diselelsaikan or fulfilled.

2) Information Research (Information Search) at this stage, consumers is looking for as much information as possible on alternative choices of goods or services needed and desired.

3) Evaluation of Alternatives the consumer will evaluate the benefits of the product or service to be purchased from the various alternatives available.

4) Purchase Decision Purchase Decision At this stage the customer has made a choice of one alternative and made a purchase.

5) Postpurchase Decision (Post Purchase Behavior) At the post-purchase stage, consumers will experience levels of satisfaction and dissatisfaction [11].

From the above explanation, the hypothesis can be stated as follows:

H3 = Motivation and Consumer Perceptions Influence Purchasing Decisions.

In this case the focus of this study is centered on consumer motivation and consumer perceptions as internal factors that can influence consumer purchasing decisions. Consumer behavior can be measured through the factors that shape Consumer Motivation and Consumer Perception of Chat Time during the Covid 19 Pandemic. Furthermore, the limitation of this study is the result of consumer perceptions or at the interpretation stage. The reason is because it turns out that interpretation is the most important stage in perception, the interpretation of the information we get through one of our senses. We cannot interpret the meaning directly, but rather interpret the meaning or information that we believe. The knowledge we acquire through perception is not knowledge of the real object, but knowledge of what the object looks like [12].

\section{METHODOLOGY}

The type of research used is seen based on the formulation of the problem that has been described, where the type of research used is descriptive associative research. "Descriptive is a type of research that is concerned with finding out statements related to the existence of independent variables". In this study, it is used to describe the consumer motivation variable. Consumer Perceptions of Purchase Decisions Whereas "associative is a type of research that aims to determine the effect or relationship between two or more variables". In this study the relationship is with causal associative, because to find out how much influence the motivation variable has consumers on purchasing decisions, consumer perceptions of purchasing decisions and consumer motivation and consumer perceptions of purchasing decisions.

\subsection{Sample and Procedure}

The population in this study were Chatime consumers with a sample size of 100 people. Measurement of variables used in this study is the Likert scale and multiple choice questions. The number of scales used for this questionnaire is five scales.

\subsection{Measure and Analysis}

Furthermore, spas Version 24 are used to test the validity and reliability. Then, in conducting data testing techniques, multiple linear regression models are used. So the $t$ test and $F$ test are used as tools in analyzing data.

\section{RESULT AND DISCUSSION}

\subsection{Purchasing Decisions The}

4.1.1. Following are the results of the analysis obtained from 100 respondents regarding purchasing decisions for each indicator:

Table 1 Perceived Need

\begin{tabular}{clc}
\hline No. & Statement of Perceived Needs & Score \\
\hline 1 & $\begin{array}{l}\text { I bought Chat time out of curiosity } \\
2\end{array}$ & 3.45 \\
& $\begin{array}{l}\text { I am interested in buying Chat time } \\
\text { because it follows current trends }\end{array}$ & 2.54 \\
3 & $\begin{array}{l}\text { Every time I go to the mall I always } \\
\text { buy Chat time }\end{array}$ & 2.19 \\
4 & $\begin{array}{l}\text { I buy Chat time because my friends } \\
\text { buy it } \\
\text { Chat time can satisfy the taste my }\end{array}$ & 2.47 \\
\hline 6 & $\begin{array}{l}\text { Whirst } \\
\text { When I want a sweet drink I buy }\end{array}$ & 2.75 \\
7 & $\begin{array}{l}\text { Chat time } \\
\text { When I want a sweet drink I buy } \\
\text { Chat time }\end{array}$ & 2.75 \\
& $\begin{array}{l}\text { I buy Chatime because I am a fan of } \\
\text { bubble tea } \\
\text { the average score was }\end{array}$ & 2.93 \\
\hline
\end{tabular}

From the score of each statement in Table 1, the indicator of the perceived need can be averaged for the score of the indicator itself of 2.82 which shows the criteria are quite good. 
Table 2 Activities before buying

\begin{tabular}{|c|c|c|}
\hline No. & Activity before buying Statement & Score \\
\hline 8 & $\begin{array}{l}\text { I always look for customer } \\
\text { reviews before deciding to buy } \\
\text { Chatime }\end{array}$ & 2.71 \\
\hline 9 & $\begin{array}{l}\text { I always look for the Chatime } \\
\text { price list before I decide to buy it }\end{array}$ & 3.67 \\
\hline 10 & $\begin{array}{l}\text { I always find out what menus are } \\
\text { available before buying Chatime }\end{array}$ & 3.78 \\
\hline 11 & $\begin{array}{l}\text { I always find out what flavors and } \\
\text { toppings are available must try } \\
\text { when buying Chatime }\end{array}$ & 3.63 \\
\hline 12 & $\begin{array}{l}\text { I bought Chatime only during the } \\
\text { promo }\end{array}$ & 2.68 \\
\hline 13 & $\begin{array}{l}\text { I bought Chatime which is } \\
\text { located close to where I live }\end{array}$ & 3.75 \\
\hline 14 & $\begin{array}{l}\text { The Chatime store feels } \\
\text { comfortable }\end{array}$ & 3.42 \\
\hline 15 & $\begin{array}{l}\text { The Chatime store is easy to find } \\
\text { because it is located in big malls }\end{array}$ & 4.14 \\
\hline \multirow[t]{2}{*}{16} & $\begin{array}{l}\text { I buy Chatime for hygienic } \\
\text { service }\end{array}$ & 3.68 \\
\hline & The average score is & 3.58. \\
\hline
\end{tabular}

From the score of each statement in Table 2, the activity indicators before buying can be averaged for the score of the indicator itself of 3.58 which shows good criteria.

Table 3 Buying Time Behavior

\begin{tabular}{lll}
\hline No. & $\begin{array}{l}\text { Statement of Behavior when } \\
\text { purchasing }\end{array}$ & Score \\
\hline 17 & $\begin{array}{l}\text { My mood increased when buying } \\
\text { Chatime }\end{array}$ & 3.21 \\
18 & $\begin{array}{l}\text { quality and taste of Chatime is } \\
\text { comparable to the price }\end{array}$ & 3.6 \\
19 & $\begin{array}{l}\text { Because Chatime is one of the most } \\
\text { popular bubble teas, I feel more } \\
\text { prestigious when buying it }\end{array}$ \\
20 & $\begin{array}{l}\text { By buying Chatime my confidence } \\
\text { has increased }\end{array}$ & 2.49 \\
21 & $\begin{array}{l}\text { Drink Chatime according to my } \\
\text { expectations } \\
\text { I felt proud when I bought Chatime }\end{array}$ & 3.53 \\
& 2.6 \\
\hline
\end{tabular}

From the score of each statement in Table 3, indicator the purchase time behavior can be averaged for the score of the indicator itself of 3.1 which shows the criteria are quite good.

Table 4 Post Purchase Behavior

\begin{tabular}{cll}
\hline No. & Statement Post-purchase Behavior & Score \\
\hline 23 & $\begin{array}{l}\text { I always feel satisfied when buying } \\
\text { Chatime }\end{array}$ & 3.26 \\
24 & $\begin{array}{l}\text { I always buy Chatime because it } \\
\text { suits my taste }\end{array}$ & 3.59 \\
25 & $\begin{array}{l}\text { I often buy Chatime because the } \\
\text { price is more affordable than other }\end{array}$ & 2.55 \\
brands & $\begin{array}{l}\text { Every time I buy Chatime I always } \\
\text { post it on social media }\end{array}$ & 2.28 \\
27 & $\begin{array}{l}\text { I recommend Chatime to my } \\
\text { friends or relatives }\end{array}$ & 3.04 \\
28 & $\begin{array}{l}\text { I leave a review on social media } \\
\text { regarding Chatime }\end{array}$ & 2.19 \\
29 & $\begin{array}{l}\text { I am curious about other Chatime } \\
\text { menus and are interested in trying } \\
\text { them }\end{array}$ & 3.35 \\
30 & $\begin{array}{l}\text { I am interested in registering as a } \\
\text { member of Chatime } \\
\text { the average score was }\end{array}$ & 2.9 \\
\hline
\end{tabular}

From the score of each statement in Table 4, the indicators of post-purchase behavior can be averaged for the score of the indicator itself of 3.84 which shows that the criteria are quite good. For purchasing decisions, we can conclude that before buying activities have the highest score, namely 3.58 , this shows that the respondent is always looking for information about what to buy, and the perceived need is the lowest score of 2.82, this is because The main need of humans in releasing their thirst is mineral water, in addition to its usefulness, mineral water does not contain ingredients that can become complications when consumed at certain times. As we know, the average fusion drink has sugar content and even contains saturated fat which is not good if consumed in excess, because the risks include diabetes.

\subsection{Hypothesis Testing}

\subsubsection{Multiple Linear Regression}

For multiple linear regression seen based on the results of the output Coefficients below. 
Table 5 Regresssed Linier multiple

\begin{tabular}{|c|c|c|c|c|}
\hline \multicolumn{5}{|c|}{ Coefficients } \\
\hline & & \multicolumn{2}{|c|}{$\begin{array}{l}\text { Unstandardized } \\
\text { Coefficients }\end{array}$} & \multirow{2}{*}{$\begin{array}{c}\begin{array}{c}\text { Standardized } \\
\text { Coefficients }\end{array} \\
\text { Beta }\end{array}$} \\
\hline & & B & $\begin{array}{l}\text { Std. } \\
\text { Error }\end{array}$ & \\
\hline \multirow[t]{3}{*}{1} & (Constant) & 5.277 & 2.419 & \\
\hline & $\begin{array}{l}\text { Purchase } \\
\text { Motivation }\end{array}$ & .524 & .099 & .510 \\
\hline & $\begin{array}{l}\text { Consumer } \\
\text { Perception }\end{array}$ & .299 & .087 & .309 \\
\hline
\end{tabular}

a. Dependent Variable: Purchasing Decisions

Based on Table 5, the value of B Constant is 5.277, Purchase Motivation is 0.524 and 0.299 Consumer Perception is. Then the multiple regression model in this study is $\mathrm{Y}=5.277+0.524 \mathrm{X} 1+0.299 \mathrm{X} 2+\mathrm{e}$.

\subsubsection{Multiple Correlation Coefficients}

For multiple correlation coefficients seen based on the results of the Summary Model (See Table 6).

Table 6 Multiple Correlation Coefficient

\begin{tabular}{ccccc}
\hline Model & $\mathrm{R}$ & $\begin{array}{c}\mathrm{R} \\
\text { Square }\end{array}$ & $\begin{array}{c}\text { Adjusted } \\
\text { R Square }\end{array}$ & $\begin{array}{c}\text { Std. Error } \\
\text { of the } \\
\text { Estimate }\end{array}$ \\
\hline 1 & $.750 \mathrm{a}$ & .588 & .579 & 3.451 .305 \\
\hline a. & $\begin{array}{l}\text { Predictors : (Constant), Consumer Perception } \\
\text { b. }\end{array}$ & & Purchase Motivation
\end{tabular}

Based on Table 6 , the $\mathrm{R}$ value is 0.750 , which is in the range of $0.61-0.80$, which is a strong correlation criterion. So it can be concluded that there is a strong relationship betweenvariables Purchase Motivation and Consumer Perception with Purchasing Decisions

\subsubsection{The Coefficient of Determination}

For the coefficient of determination is seen based on the output of the Summery Model (See Table 7).

Table 7 The coefficient of determination Model Summary

\begin{tabular}{lcrrr}
\hline Model & R & R Square & $\begin{array}{c}\text { Adjusted } \\
\text { R Square }\end{array}$ & $\begin{array}{c}\text { Std. Error } \\
\text { of the } \\
\text { Estimate }\end{array}$ \\
\hline 1 & $.763 a$ & .570 & .569 & $3,451,305$ \\
\hline $\begin{array}{l}\text { a. Predictors: (Constant), Consumer Perception } \\
\text { Purchase Motivation }\end{array}$
\end{tabular}

Based on Table 7, the R Square value is 0.578 , which means that the influence of the Purchasing Motivation and Consumer Perception variables variable on the Purchasing Decision is $57.01 \%$. While the contribution of the Purchasing Motivation and Consumer Perception variables to the variable Purchasing Decision is partially searched by using the formula SE (X)\% = Beta x xrxy $\mathrm{x}$ $100 \%$, so that the contribution of the variable Purchasing Motivation is $36.25 \%$ and the contribution is large. Variable Consumer Perception amounted to $20.76 \%$.

\subsubsection{T Test}

Test For the $\mathrm{t}$ test, it is based on the results of the output coefficients.

Table 8 t-Test Coefficients

\begin{tabular}{cccccc}
\hline & \multicolumn{5}{c}{$\begin{array}{c}\text { Unstandardized } \\
\text { Coefficients }\end{array}$} \\
\cline { 3 - 4 } & Model & B & Std. Error & T & Sig. \\
\hline 1 & (Constant) & $5,267,407$ & $2,409,374$ & 2,186 & .031 \\
& $\begin{array}{c}\text { Purchase } \\
\text { Motivation }\end{array}$ & .513 & .095 & 5.286 & .000 \\
$\begin{array}{c}\text { Consumer } \\
\text { Perception }\end{array}$ & .289 & .078 & 3.175 & .001 \\
\hline
\end{tabular}

a. Dependent Variable: Purchase Decision

Based on Table 8 , the value of the variable $t$ for Purchase Motivation and Consumer Perception is 5,286 and 3,175 where the value is $>\mathrm{t}$ table 1,985 . Meanwhile, the Sig. for the variables Purchasing Motivation and Consumer Perception are 0.000 and 0.001 . This means that there is a significant influence between the variable Purchasing Motivation on the Purchasing Decision partially, and there is a partially significant influence between the variable Consumer Perception on the Purchasing Decision. So it can be concluded that the hypothesis is accepted.

\subsubsection{F test}

For the F test, it is seen based on the ANOVA output.

Table $9 \mathrm{~F}$ test ANOVA

\begin{tabular}{llrcc}
\hline Model & & Df & F & Sig. \\
\hline 1 & Regression & 2 & 65.366 & $.000 \mathrm{~b}$ \\
& Residual & 97 & & \\
& Total & 99 & & \\
\hline
\end{tabular}

a. Dependent Variable: Busing decision

b. Predictors: (Constant), Consumer Perception, Purchase Motivation 
Based on Table 8, the F value is 65.366 , which is $>\mathrm{F}$ table 3.09. As well as the Sig. 0,000 where the value is $<0.05$. So it can be concluded that there is a significant influence between Purchase Motivation and Consumer Perception of Purchasing Decisions simultaneously, which means that the hypothesis is accepted.

\section{CONCLUSION}

Based on the research and data analysis that has been done in this research, the researchers conclude that:

1. Purchasing decisions produce indicators of perceived needs, pre-purchase activities, purchase time behavior and post-purchase behavior, in this case the information-seeking perspective is considered to be the most important thing, including making purchases, so that individual attitude patterns are also reflected with high curiosity. In this case the pandemic does not change the pattern of decisions usually made by consumers where everything is much more considered and also requires more information to make decisions about buying chat time beverage products, product quality is one of the highest indications in shaping consumer perceptions .Individuals may look at one thing, the same thing but perceive or describe it differently in terms of being in line with the description of the perception formation process which fulfills the functions of products and services both from the perspective, features of product reliability, durability, suitability and service and aesthetics so that they can It is also assumed that Chattime is quite capable of becoming one of the brands that in the end has a positioning as the most superior product considering the fulfillment of all the complementary elements of quality which in the end is able to survive in building a good and maintained perception even in the midst of the current pandemic compared to other competitors. . In its implication, Rational motivation is still a reference for consumers in using the most used motivation in today's consumer attitude patterns. This means that even though consumers use fusion drink only as a re-creation drink, the indication of the calculation which is reflected in the price, quality of service and promotional products remains the main aspect of consideration for consumers, of course, to motivate themselves in making purchasing decisions during pandemic

2. The results showed that the influence of the Purchasing Motivation variable to the purchase decision amounted to $36.25 \%$, which is a variable that has a more dominant influence in this study. This shows that the Purchase Motivation variable has a stronger influence in influencing customers to make Purchase Decisions on brand chat time brands
3. The results showed that the influence of consumer perceptions to the Purchase Decision amounted to $20.76 \%$, which is the variable that has the least influence in this study. This shows that the Consumer Perception variable has a weak influence in influencing customers to purchase decisions on brand chat time

4. The research results show that the influence of Purchasing Motivation is great and Consumer Perception to the Purchase Decision amounted to $57.01 \%$ and the other $42.99 \%$ influenced by other variables not examined in this study. This shows that Purchase Motivation and Consumer Perception not so much influence in influencing customers to make Purchase Decisions on brand chat time brands.

\section{REFERENCES}

[1] V. F. Pangkey, S. J. Lapian, F. Tumewu. The Analytical Hierarchy Process (Ahp) Of Consumer Purchase Decision In Selecting Bubble Tea Shop. Jurnal Emba: Jurnal Riset Ekonomi, Manajemen, Bisnis Dan Akuntansi, 4 (2) (2016) 12-24. DOI: https://doi.org/10.35794/emba.v4i2.13043

[2] N. Lailla, J. Hananto. The Effect of Packaging and Price on the Chatime Drink Purchase Decision (Case Study in Tangerang Selatan). KnE Social Sciences, (2019) 1033-1050. DOI: https://doi.org/10.18502/kss. v3i26.5429

[3] P. Kotler, K. Keller. Marketing management 14th edition. prentice Hall, 2011.

[4] S. Auray, A. Eyquem. The macroeconomic effects of lockdown policies. Journal of public economics, 190 (2020) 104260. DOI: https://doi.org/10.1016/j.jpubeco. 2020.104260

[5] H. Handoko. Manajemen Personalia dan Sumber Daya Manusia Yogyakarta. BPFE Yogyakarta, 2011.

[6] L. G. Schiffman, L. L. Kanuk. Consumer Behaviour, 8th Ed. Great Britain: Pearson Education International. 2004

[7] M. Solomon, R. Russell-Bennett, J. Previte. Consu mer behaviour. New York: Pearson Higher Education 2012.

[8] R. A. Firdaus, D. Purnamasari, S. F. Akuba. The influence of motivation, leadership and perceived workload as intervening on teacher commitment.Jour 
nal of Educational Science and Technology (EST), 5 (3) (2019) 268-276. DOI: https://doi.org/10.26858/est.v

$5 \mathrm{i} 3.10847$

[9] X. Zhang, X. Bai, J. Shang. Is subsidized electric vehicles adoption sustainable: Consumers' perceptions and motivation toward incentive policies, environmental benefits, and risks. Journal of Cleaner Production, 192 (2018) 71-79. DOI: https://doi.org/10. 1016/j.jclepro.2018.04.252

[10] A. Chen, Y. Lu, B. Wang. Customers' purchase decision-making process in social commerce: A social learning perspective. International Journal of Information Management, 37 (6) (2017) 627-638. DOI: https://doi.org/10.1016/j.ijinfomgt.2017.05.001

[11] P. Kotler, G. Armstrong. Principal Of Marketing. New Jersey: Pearson Education, Inc, 2012

[12] L. Suhaily, S. Darmoyo. Effect of product quality, perceived price and brand image on purchase decision mediated by customer trust (study on japanese brand electronic product). Jurnal Manajemen, 21 (2) (2017) 179-194. DOI: http://dx.doi.org/10.24912/jm.v21i2.

230 